\title{
PEDRO DE OSMA AND THE REHABILITATION OF ARISTOTELIAN PRACTICAL PHILOSOPHY IN THE 15TH CENTURY ${ }^{*}$
}

\section{PEDRO DE OSMA Y LA REHABILITACIÓN DE LA FILOSOFÍA PRÁCTICA ARISTOTÉLICA EN EL SIGLO XV}

SEBASTIÁN CONTRERAS A. Universidad de los Andes, Chile

\begin{abstract}
Pedro de Osma plays a major role in the reception of Aristotle's practical philosophy. In his extensive commentary on the Ethica Nicomachea, he expounds in detail the main themes of Aristotelian morality, such as the content of the ultimate end or the distinction between the natural and the legal just. He paved the way for Vitoria and the so-called Salamanca 'jurist-theologians,' and marked a watershed between medieval and Renaissance Aristotelianism.
\end{abstract}

Keywords: Pedro Martínez de Osma, Aristotle, Aristotelianism, Ethica Nicomachea, practical philosophy.

\section{RESUMEN}

* The author gratefully acknowledges the support of FONDECYT-Chile, project 1180510, as well as the VicePresidency for Research of the Universidad de los Andes, Chile. 
La historia de la recepción de la filosofía práctica de Aristóteles tiene a Pedro de Osma como un actor principal. En su extenso comentario a la Ethica Nicomachea expone con detalle los principales temas de la moral aristotélica, como la cuestión del fin último o la distinción entre lo justo natural y lo justo legal, adelantándose a Vitoria y a los llamados 'juristas-teólogos' de Salamanca, y marcando un punto de inflexión entre el aristotelismo medieval y el aristotelismo renacentista.

Palabras clave: Pedro Martínez de Osma, Aristóteles, aristotelismo, Ethica Nicomachea, filosofía práctica

Pedro de Osma (Martínez de Osma) significantly contributed to the rehabilitation of Aristotle's practical philosophy towards the end of the Middle Ages. His extensive commentary on the Ethica — which takes into account the Latin jurists, the Holy Fathers and the scholastic philosophers - set the background for the transition from medieval Aristotelianism to the Aristotelianism of the so-called 'jurist-theologians' of Salamanca.

Just like his disciple and friend Fernando de Roa, Osma echoes St. Thomas. He introduced Thomas Aquinas to the Spanish theologians - although he does only seldom explicitly quote him. ${ }^{1}$ Spanish Thomism did not spontaneously sprout after Vitoria's arrival at the University of Salamanca. Thanks to Osma, as well as to many theology professors who flourished there betwixt Osma and Vitoria, Thomism became the backbone of early modern Scholasticism. ${ }^{2}$

The history of ethics has not done justice to Osma's contribution. For example, only a handful of writings discuss his theory of justice. He also deserves a greater consideration in the history of Aristotelianism. Most studies on the reception of Aristotle's philosophy barely mention Osma as one representative in the development of that current in Spain; they do not examine his commentaries on the Stagirite's practical philosophy. Such is, in fact, the purpose of this article.

1 Joaquín García-Huidobro, La recepción de la doctrina aristotélica de lo justo natural y lo justo legal en los comentarios medievales de la Ética a Nicómaco (Ciudad de México: UNAM/Porrúa, 2017), 168.

2 Sebastián Contreras, "Fernando de Roa y la recepción de la filosofía práctica de Aristóteles," Tópicos 57 (2019): 351-355. 
Of the various problems dealt with by Aristotle in the Ethica, Osma analyzes with special care the following four: civil society, happiness as the end of political rule, the relationship between natural and positive law, and the nature of equity.

\section{CIVIL SOCIETY AND POLITICAL REGIME}

Martínez de Osma, "the most illustrious [...] among the Spanish heterodox of the Middle Ages," 3 postulates that political society arises for the sake of common welfare, and that common welfare or happiness is achieved through just laws. ${ }^{4}$ Political society does not observe the logic of domestic societies, which pursue mere material satisfaction, for it also seeks the intellectual development of individuals. The happy life, which is the end of the republic, ${ }^{5}$ presupposes the material and spiritual wellbeing of its citizens. Men are no mere animals. Our rationality demands the pursuit of the intellectual good, which can be only achieved with much effort and the help of the legislator. Moreover, in Osma's view, legislators behave as exemplary causes and exercise a pedagogical function in relation to the citizens. ${ }^{6}$

Deprived of political society, men do not achieve their ends. According to Osma, where there is no government, people are lost. Therefore, just as a directive power is necessary in each intermediate body (e.g. families and associations) for its internal governance, so is a political government equally necessary or even more imperative in civil society.

Notwithstanding that individual welfare and the political common good coincide, ${ }^{7}$ it must be borne in mind that the common social welfare matters more than individual welfare. ${ }^{8}$ Moreover, social welfare is 'quasi-divine' and sets the standards for the conduct of good citizens and good legislators. ${ }^{9}$

Political welfare is a condition of possibility for individual welfare; thus, individuals fully develop only when the community flourishes. Osma explains that the common good is a whole in which the good of the individual participates:

3 Marcelino Menéndez Pelayo, Historia de los heterodoxos españoles: España romana y visigoda. Período de la reconquista. Erasmistas y protestantes (Madrid: BAC, 2006), 566.

4 Pedro de Osma, Commentaria in libros Ethicorum (Salamanca: Universidad Pontificia de Salamanca, 1996), f. 76.

5 Commentaria in libros Ethicorum, f. 14; f. 37; f. 134.

6 Commentaria in libros Ethicorum, f. 37.

7 Commentaria in libros Ethicorum, f. 134.

8 Commentaria in libros Ethicorum, f. 14.

9 Commentaria in libros Ethicorum, f. 35; f. 54. 
"the relationship between the citizen and the republic is the same as that between the individual good and the political common good." 10

Society arises naturally. It expresses man's rationality, and it precedes the citizen. The way in which the natural inclination to sociability takes shape in each republic depends on its historical particularities. Nevertheless, "[although] the public concern is different from place to place $[\ldots]$ and although rarely if ever do two cities have the same form of life $[\ldots]$ one is the republic which is everywhere the best." 11 Osma's reading is odd. Whenever he explains the nature of political rule, he stresses the maximum freedom to choose the most suitable regime according to the circumstances. He is probably afraid that admitting that the best government regime depends on circumstances could imply that everything in politics depends on convention. Since that is the conclusion he rejects, Osma emphasizes the absolute immutability of natural law with respect to the definition of the best regime of government: the best regime is the one that directly derives from natural law. ${ }^{12}$

Although natural law excels over legal law, natural law would be useless if the legislator did not determine it, since human actions deal with particular things. ${ }^{13}$ Natural norms alone, which are abstract and universal, cannot address every human problem.

Following Aristotle, Osma apparently holds that the best political regime is the monarchy. The commentaries to the Politica take this view too. ${ }^{14}$ However, it is perhaps not Osma's strict position. Indeed, the commentaries on the Politica were jointly written by Fernando de Roa and Pedro de Osma; perhaps only Roa deemed monarchy as the best government regime. The doubt is justified if we consider that, in the sermon Corripiens eos qui indiscrete petunt, which was exclusively authored by Osma, he defends that a regime of active participation of the citizens is better than monarchy. Thus, for the Osma of this minor writing, the popularis principatus outdoes any other form of government. ${ }^{15}$

10 Commentaria in libros Ethicorum, f. 14.

11 "... [the republic that is everywhere the best] is that which is understood to be instituted by natural law. Thus, just as natural rights are everywhere the same, so the natural public concern derived from natural law will be the same everywhere" (f. 90).

12 Commentaria in libros Ethicorum, f. 90.

13 Commentaria in libros Ethicorum, f. 90.

14 Pedro de Osma \& Fernando de Roa, Commentarii in Politicorum libros (Salamanca: Universidad Pontificia de Salamanca, 2006), ff. 5-ss.

15 Pedro de Osma, Sermo corripiens eos qui indiscrete petunt (Manuscritos de autores medievales hispanos, Madrid: CSIC, 1987), f. 39v (38v). 


\section{HAPPINESS AS THE END OF POLITICAL GOVERNMENT}

The happiness of the republic matters more than individual happiness and is the end of political activity. ${ }^{16}$ Therefore, the ruler does not focus on individual happiness, but on the happiness of the whole. ${ }^{17}$ That happiness is named in the political realm 'the common good,' which consists of the minimal conditions required by human nature to fully develop.

In continuity with Aristotle, Osma explains that, among human goods, happiness is the first, since it is the good which everyone aspires to as the end of their desires. It is not the good to which all things are directed, "but the good related to us [as men]." ${ }^{, 18}$ This good can be taken in two senses: as referring to a genus and in an absolute way. As to the first sense, there can be many ultimate ends, such as health in medicine or victory in strategy. In the second sense, that is, in an absolute sense, there is only one ultimate end, which is called happiness or the highest good of man. ${ }^{19}$

Since there is only one human good, "that thesis according to which it is affirmed that there are two happinesses, one contemplative and the other active, is false. Those who subscribe to that opinion have not understood Aristotle, since it is contrary to what he explicitly says in the Ethica Nicomachea." 20 "That reading," says Osma, "which once seemed correct to me, is false because [...] if there were two happinesses, since happiness is the first principle of acts, there would be two first principles for man, something that Aristotle rejects in the Metaphysica. If there were two happinesses, or if they were equal in perfection, one would be useless and one would be the better [...] That of lesser perfection could not be known as happiness, for happiness is the highest good, as Aristotle says. Consequently: to postulate that the first book of the Ethica Nicomachea speaks of a happiness different to the one of the tenth book is erroneous, because the first book only says that happiness is an activity of the soul in accordance with perfect virtue [...] while the tenth book postulates that this happiness is not proper to the moral, but to the intellectual field, and that it refers to the virtue of wisdom."."21

16 Commentaria in libros Ethicorum, f. 14.

17 Commentaria in libros Ethicorum, ff. 12-14.

18 Commentaria in libros Ethicorum, f. 12.

19 Commentaria in libros Ethicorum, f. 24.

20 Commentaria in libros Ethicorum, f. 24.

21 Commentaria in libros Ethicorum, f. 133. "To advocate a variety of happinesses is contrary to Aristotle and the truth of things" (ff. 133-134). "The mistaken distinction between two happinesses 
The highest good can be neither health, nor physical beauty, nor sensible knowledge, for those goods are not properly human. Nor can it be the exercise of appetite rectified by reason, because understanding is better than appetite. The highest good must be the activity of the speculative intellect, which is the best in man. $^{22}$

Each one's happiness is beautiful and contained in the political good, ${ }^{23}$ since the good of man and the good of the city are one. ${ }^{24}$ The rulers, for this reason, must seek happiness - the good of the subject and of the city - as the goal of their government. If they do not do so, their norms will not be laws, but acts of tyranny, and should not be enforced for any reason. ${ }^{25}$ The greater or lesser pursuit of happiness by the government is, so to speak, a criterion for ascertaining its greater or lesser legitimacy as a ruler. ${ }^{26}$

\section{NATURAL LAW AND POSITIVE LAW}

With Osma, the difference between natural and legal law becomes a general theory of virtue. All virtues, he points out, have legal and natural aspects. ${ }^{27} \mathrm{He}$ means that, in all virtues, some elements are common to all men (natural) and some conventional (legal): drinking in excess is always unnatural, but the precise measure of what one should drink may be determined by convention or context; hence, it is legally determined.

Osma, like St. Thomas, remarks that natural law is not a right of nature but of reason. The zoological interpretation of natural law gives no space to reason as

cannot be defended. Were there two happinesses [...] there would be two ultimate ends and two activities of man as man [...] and two supreme virtues, which is an absurdity" (f. 27).

22 Osma reasons as follows: "in the first place, it must be borne in mind that happiness is not in health or physical beauty [...] because these things are proper to vegetative life. Secondly, that happiness is not in sensible knowledge or in sensible pleasure, for these are things proper to animal life. And, thirdly, that happiness is also not in the activity of the appetite rectified by reason [...] for, as Aristotle says, the intellect is better than the appetite - and its function is better. Happiness can only be in the act of the speculative intellect" (f. 26).

23 Commentaria in libros Ethicorum, f. 30.

24 "The good of one and the good of the republic are the same. Therefore, just as the good of one is contemplation, so the good of the republic will be contemplative activity" (ff. 133-134).

25 Commentaria in libros Ethicorum, f. 129.

26 Commentaria in libros Ethicorum, f. 37.

27 Commentaria in libros Ethicorum, ff. 88-89. "Thus, there will be something legally honest and something naturally honest. Therefore, in fortitude, temperance, liberality, and the other virtues, that which is common to all peoples will be naturally honest. On the contrary, things that are diverse among different peoples do not have the character of being naturally honest; they are so only by law or custom. Such, in that way, are not said to be natural but legal." 
an instance of normative appeal, which is how Osma understands the practical reason of Aristotle and Thomas Aquinas.

Natural law does not cover every social problem. It must be historicized and determined, for which human intervention is decisive. The legislators, whose activity is directed to the achievement of political happiness, have the widest freedom to concretize natural law according to the particularities of their civil societies. They should only refrain from contradicting the fundamental moral principles and the mandates of divine law. The mere infringement of these precepts renders the legislator's determinations unjust and resistible. ${ }^{28}$

The determination of positive law is a historical and prudential process, in which the authority must weigh the particular needs of civil society with the demands of natural justice. ${ }^{29}$ The legislator 'determines' ('concretizes,' 'specifies') moral precepts according to changing circumstances; the ensuing positive laws may be appropriate for one community and unsuitable for another. The historical contingency is so great that it is impossible to apodictically deduce positive laws from natural law. Further, determination is a fallible process, because it is impossible to reason in juridical matters with the same level of certainty as in mathematics. ${ }^{30}$

Both forms of the just, i.e. the legal and the natural, take place within the republic. It is true that they present different physiognomies, since legal law does not only change from society to society, but, within the same society, it owes its origin not to one but to many legislators. Nonetheless, the different legislative decisions retain a fundamental unity through their common purpose: since their aim is one and the same, all laws of the republic, even if they have been enacted by different legislators, must be considered as one. ${ }^{31}$

Osma thinks that positive laws stem from natural law in the same way that individuals stem from their species. According to this scholastic, individuals exist because species must be concretized in particular cases. Likewise, legal rights

28 Beyond this limit, the legislator can choose the normative option that seems best to him. In matters of determination and positive law, almost everything is open to opinion.

29 This law is changeable. To understand this statement, Osma adds the following remark: "First, those who say that the laws of any republic must remain the same forever are deeply mistaken. Such a thing would be unjust unless the republic were always under the same situation, which is very unusual. Second, those who think that all men should be subject to the same rules are equally mistaken, since men are different in different places and are distinguished by nature and custom. In sum [...] many laws are good in one republic and bad in others."

30 Commentaria in libros Ethicorum, f. 16.

31 García-Huidobro, La recepción de la doctrina..., 170. 
exist because natural rights require to be concretized in particular positive laws. ${ }^{32}$ Thereby, Osma elaborates on St. Thomas' via determinationis, for he argues that the relationship between positive law and natural law is the same as that between the individual and the species.

Osma writes that natural law is in actuality a whole containing many singulars, i.e. "natural law can contain many legal rights, like the universal, which contains in itself a multitude of things." 33 This same relationship exists, this author points out, between positive law and the acts it regulates. ${ }^{34}$

The lawgiver determines natural law like a doctor attending a sick person and to whom he prescribes the most suitable medicine..$^{35}$ The legislator also imitates a father who cares for his children or, to express it in logical terms, a whole caring for its parts: "the legislator, in passing laws, acts as a whole caring for its parts. It should be noted that, although a man sometimes seems to care for a sick hand or a sick finger, he cares neither for the hand nor for that finger, but for himself. That is his intention. Therefore, this man wants the health of the finger because he seeks his own health. The legislator acts similarly: when he dictates laws $[\ldots]$ he really seeks the benefit and health of the whole social body." ${ }^{36}$

Positive laws, lastly, aim at rendering its subjects good citizens. Osma solves the classic dilemma of whether the legislator should seek the absolute or only the relative good (i.e. only the political good) of the citizens by distinguishing the end and means of ethics from that of law. The political science, to which law and morality belong, seeks to render citizens good and virtuous. ${ }^{37}$ However, morality, which seeks to make men absolutely good, operates by means of persuasion; and law, which seeks to make them relatively good, by coercive force. ${ }^{38}$

32 Commentaria in libros Ethicorum, f. 89.

33 Commentaria in libros Ethicorum, f. 89.

34 “... any right is a universal under which infinite matters are contained. This says [Aristotle in the Ethica]. And from this text you will notice that, although legal rights are particular with respect to natural ones, nevertheless there is not and cannot be any legal right which is not universal. And this in regard to particular matters; which you will well notice against the ineptitudes of those who judge that legal rights are purely particular; for legal rights are like subaltern genera."

35 Commentaria in libros Ethicorum, f. 19.

36 Commentaria in libros Ethicorum, f. 88.

37 Commentaria in libros Ethicorum, f. 37.

38 Commentaria in libros Ethicorum, f. 32. 


\section{POSITIVE LAW AND EQUITY}

Positive law is a principle of action that is general in character and commands according to what happens most of the time. It deals with all things that occur in the republic, ${ }^{39}$ especially those that are useful for temporal tranquility, ${ }^{40}$ and regulates the acts that are necessary to achieve happiness. ${ }^{41}$ Equity, on the other hand, is an amendment of positive law. ${ }^{42}$ The law is corrected in view of a concrete case from its maximally general character, for the law must ignore in its formulation the exceptions that do not conform to a universal judgment. The judge has no faculty to neglect the law, yet the law has not considered the particularities of the case with which the judge is confronted. As is evident, the judge cannot decide beyond the law but according to the spirit of the law. ${ }^{43}$

The very general nature of the law is not a problem. The problem lies in the contingency of human acts. Positive law cannot cover every conceivable circumstance. In fact, it should not deal with extraordinary circumstances. ${ }^{44}$

The literal application of law sometimes accomplishes an injustice. In these cases, the judge must interpret the letter of the law according to the spirit of the legislator (Osma thinks that, if the legislator knew these cases, he would certainly modify the law ${ }^{45}$ ). Now, the correction of the law must be based on natural justice. This corrective act is a direct invocation of natural law, and the primacy of this law over positive law is confirmed when amending the silence of the legislator. 


\section{CONCLUSION}

Osma, the great Aristotelian of the so-called First School of Salamanca, ${ }^{46}$ visibly contributed to the revival Aquinas' philosophy in the orbit of Spanish thinkers. This program leads him to read Aristotle through St. Thomas lenses when he addresses the questions on the ultimate end and on the Aristotelian theory of justice. Thus, Osma maintains that all the laws of the republic are related to each other and that they hold a certain unity, a thesis that inescapably resembles the Thomistic idea that all moral principles have the same root, namely, the first of the first principles of natural law.

The better or worse performance of rulers affects the happiness of the citizens. Thus, for Osma, the pursuit of happiness distinguishes good from bad rulers. Whoever governs correctly aspires to the good of all citizens, which is the activity of prudence and - more perfectly — the activity of contemplation. However, we should not think that practical life and contemplation are dissociated. The activity in accordance with the virtue of the first book of the Ethica Nicomachea is the activity of wisdom according to the text of the tenth book.

It is not surprising, finally, that Osma's Aristotelianism is intermingled with St. Thomas' Aristotelianism, and even with what his friend and disciple Fernando de Roa conceives as the authentic doctrine of the Stagirite. Aristotelianism has never been a closed current. Rather than a rigid school of thought, it is a great tradition that is always open to be reinterpreted and adapted to new political and social problems that require a solution in accordance with the principles of the so-called Central Tradition of the West.

46 Antonio de Nebrija, a disciple of Osma who disagrees with him on almost every subject, is very laudatory when he speaks of his teacher: "I am going to say something that is on everyone's lips and that has really happened. No one is unaware of how great the talent and erudition of master Pedro de Osma was; since [Osma], after the famous Tostado — who after being professor in Salamanca became bishop of Avila - was in my view, and according to the opinion of all, the most outstanding of our time in all kinds of knowledge" (Apologia, $\S 15)$. 


\section{BIBLIOGRAPHICAL REFERENCES}

Contreras A., Sebastián. "Fernando de Roa y la recepción de la filosofía práctica de Aristóteles." Tópicos 57 (2019): 349-374.

García-Huidobro, Joaquín. La recepción de la doctrina aristotélica de lo justo natural y lo justo legal en los comentarios medievales de la Ética a Nicómaco. Ciudad de México: UNAM/Porrúa, 2017.

Menéndez Pelayo, Marcelino. Historia de los heterodoxos españoles: España romana y visigoda. Periodo de la reconquista. Erasmistas y protestantes. Madrid: BAC, 2006.

Nebrija, Antonio de. Apologia. Huelva: Universidad de Huelva, 2014.

Osma, Pedro de. Commentaria in libros Ethicorum. Salamanca: Universidad Pontificia de Salamanca, 1996.

Osma, Pedro de. Sermo corripiens eos qui indiscrete petunt (Manuscritos de autores medievales hispanos). Madrid: CSIC, 1987.

Osma, Pedro de \& Roa, Fernando de. Commentarii in Politicorum libros. Salamanca: Universidad Pontificia de Salamanca, 2006.

Sebastián Contreras A. Universidad de los Andes, Chile Law School Álvaro del Portillo \#12.455

7620001 Santiago (Chile) https://orcid.org/0000-0002-4517-5600 
